\title{
Kriminalisasi dalam Peraturan-peraturan Daerah di Propinsi Daerah Istimewa Yogyakarta dalam Perspektif Politik Kriminal
}

\author{
M. Arif Setiawan
}

\begin{abstract}
There is any trend of criminal threat in the endorsed laws in Yogyakarta Special province. It especially deals with the regional tax viewed from criminal punishment perspective has been proportioned as the norm of regulation. It seems that to be forced socially and economically. The main aim of enclosing criminal sanction on regulation non-criminal punishment is actually for forcing in order that society meet the Endorse Laws.
\end{abstract}

\section{Pendahuluan}

Hukum pidana dibangun di atas tiga konsep utama yaitu: tindak pidana, kesalahan dan hukuman pidana.' Tiga konsep tersebut menurut Packer menimbulkan tiga masalah mendasar dalam hukum pidana yaitu: (1) what conduct should be designated as criminal; (2) what determinations must be made before a person can be found to have committed a criminal offence; (3) what should be done with persons who are found to have committed criminal offences. ${ }^{2}$

Yang dimaksudkan dengan istilah pemidanaan adalah pengenaan ancaman sanksi pidana yang dijatuhkan kepada seseorang yang dinyatakan bersalah secara sah oleh Hakim pengadilan karena telah melakukan perbuatan yang dilarang dalam hukum pidana atau bahkan mungkin tidak melakukan perbuatan yang seharusnya justru wajib dilakukan. Packer mengartikan istilah pemidanaan sebagai:

1 Moeljatno, Asas-Asas Hukum Pidana (Yogyakarta: Gadjah Mada University Press, 1980). Herbert L. Packer, The Limits of The Criminal Sanction (Califomia: Stanford University Press), hlm. 9. Packer berpendapat bahwa: "The rationale of the criminal law rest on three concepts: offense, guilt, and punisment".

2 Packer, ibid. hlm. 15. 
Criminal punishment means simply any particular disposition or the range of permissible dispositions that the law authorizes (or appears to authorize) in cases of persons who have been judged through the distinctive processes of the criminal law to be guilty of crimes. Not all punishment is criminal punishment but all criminal punishment is punishment. ${ }^{3}$

Dari penjelasan Packer tersebut sekaligus ditegaskan oleh Packer bahwa yang dimaksud dengan istilah pemidanaan (criminal punishment) adalah hukuman yang dijatuhkan secara sah terhadap seseorang yang telah divonis bersalah melakukan kejahatan. Tidak semua hukuman merupakan hukuman pidana (pemidanaan), tetapi semua pemidanaan adalah hukuman.

Dari tiga konsep utama bangunan hukum pidana tersebut-tanpa bemaksud mengurangi arti penting dari dua konsep lainnya - menurut penulis masalah pemidanaan nampaknya menjadi salah satu bidang kajian yang sering mendapat "sorotan" perhatian. Banyak masalah yang berkaitan dengan aspek kemanfaatan pemidanaan yang diajukan sehubungan dengan keberadaan pemidanaan. Apakah tujuan diadakannya pemidanaan dalam hukum pidana dan apakah hal itu memang diperlukan, serta apakah pemidanaan itu memerlukan suatu pembenaran (justifikasi)? Pertanyaan-pertanyaan tersebut nampaknya sering diajukan manakala diperbincangkan masalah pemidanaan. Pembahasan dan jawaban terhadap beberapa masalah tersebut seringkali bersifat dilematis sebagaimana yang dikemukakan oleh Packer bahwa : It is a necessary but not a sufficient condition for punishment that is designed to prevent the commission of offences ${ }^{4}$ yang dengan demikian menurut Packer pemidanaan itu perlu tetapi sebenarnya tidak cukup (tidak efektif) untuk mencegah seseorang melakukan kejahatan.

Teori-teori tentang pembenaran pemidanaan pada pokoknya antara lain akan membahas masalah-masalah sebagai berikut, yaitu mengapa sanksi pidana diperlukan, siapa yang dapat menjatuhkan sanksi pidana, mengapa diperlukan pemidanaan sedang dalam beberapa hal cukup diberikan dengan peringatan saja, dan mengapa ancaman sanksi pemidanaan perlu dibatasi? ${ }^{5}$ Mengenai masalah tujuan pemidanaan, Packer mengemukakan sebagai berikut:

In my view, there are two and only two ultimate purposes to be served by criminal punishment: the deserved infliction of suffering on evildoers and the prevention of crime. It is possible to distinguish a host of more specific purposes, but in the end all of them are simply intermediate modes of one or the other of the two ultimate purposes. These two purposes are almost universally thought of as being incompatible; ...6

Dengan demikian, menurut pandangan

${ }^{3}$ Packer, ibid. hlm. 35.

4 Packer, ibid. him. 62.

${ }^{5}$ Sri Budiarti Hennyoso, Pengantar Diskusi Buku Herbert L. Packer mengenai "Justification of Criminal Punishmenf", pada Program Pascasarjana, Program Studi llmu Hukum Universitas Indonesia (Jakarta: 16 September 1993). Lihat juga Packer, ibid. hlm. 9-10.

${ }^{6}$ Packer, ibid. hlm. 36. 
Packer, hanya ada dua tujuan akhir yang hendak dicapai dengan pemidanaan, yaitu memberikan pembalasan berupa pendëritaan terhadap pelaku kejahatan untuk mencegah dilakukannya kejahatan. Menurut pendapat Packer tersebut kita memang dimungkinkan untuk membedakan tujuan spesifik, tetapi. pada akhimya semua itu hanyalah cara-cara yang sifatnya pertengahan yang termasuk dalam salah satu atau kedua tujuan akhir dari pemidanaan itu. Menurut Packer kedua tujuan akhir ini secara universal sebenarnya dianggap tidak cocok (atau bertentangan) satu dengan yang lainnya.

Berkaitan dengan macam-macam pendekatan pembenaran pemidanaan tersebut Packer sampai pada satu pandangan bahwa: Punishment is a necessary but lamentable form of social control. It is lamentable because it inflicts suffering in the name of goals whose achievement is a matter of chance. Dengan demikian menurut Packer, pemidanaan itu perlu tetapi sebenarnya merupakan suatu bentuk yang patut disesalkan. Karena pemidanaan mengakibatkan penderitaan atas nama tujuan-tujuan yang pencapaiannya adalah masalah kesempatan saja.

Hampir senada dengan pandangan Packer tersebut Gross berpandangan bahwa pemberian pidana diumpamakan sebagai a regrettable necessity, yaitu suatu keharusan yang patut disesalkan ${ }^{8}$. Pembenaran pemidanaan menurut Gross dijelaskan dengan mempergunakan perumpamaan yang ekstrim yaitu seperti antara kedermawanan (charity) dengan perbudakan (slavery). Dalam hal ini Gross menulis:

Since punishment, unlike charity, is an evil, it needs justification; and since, unlike slavery, it is not simply evil, it might be justified. Justification of punishment all perceive some grim necessity which make right in spite of the suffering and degradation it produced. ${ }^{9}$

Dengan demikian menurut Gross di atas karena pemidanaan bersifat jahat ia tidak seperti sifat kedermawanan, maka pemidanaan membutuhkan pembenaran, dan karena pemidanaan sebenarnya tidaklah

${ }^{7}$ Berdasarkan pandangannnya tersebut Packer mengemukakan adanya tiga macam pendekatan untuk melihat alasan pembenaran pemidanaan yaitu: Retribution, Utilitarian Prevention (Deterrence, dan Special Deterrence atau Intimidation), dan Behavioral Prevention (Incapasitation dan Rehabilitation). Berdasarkan tiga macam kelompok pendekatan pembenaran pemidanaan tersebut Packer sendiri mengajak untuk masuk ke dalam teori pemidanaan yang integral. Packer, ibid. hlm 35-61, 62-70.

${ }^{\theta}$ Hyman Gross, Justification of Criminal Punishment (New.York: Oxford University Press, 1979). Dalam diktat Mardjono Reksodiputro ed. Sistem Peradilan Pidana Buku / (Jakarta: Lembagà Kriminologi Universitas Indonesia), bahan kuliah, diterbitkan terbatas untuk kalangan sendiri di Program Pascasarjana IImu Hukum Universitas Indonesia, him.61.

${ }^{\circ}$ Gross, Ibid. hlm. 62. Meskipun pandangannya mengenai pemidanaan hampir sama dengan Packer, namun teori-teori pembenaran pemidanaan yang dikemukakan oleh Gross ternyata berbeda. Menurut Gross teori-teori pembenaran pemidanaan ada enam macam yaitu: (1) Removal of socially dengerous persons, (2) Rehabilitation of socially dangerous persons, (3) Paying one's debt to society, (4) Intimidation version of deterrence, (5) The persuation version of deterrence, dan (6) A preferred Theory. Lihat Gross, ibid. hlm. 66-80. 
benar-benar bersifat jahat, tidak seperti slavery, pemidanaan mungkin dibenarkan. Pemberian hukuman untuk orang-orang yang bersalah memang sesuatu yang benar.

Dari pandangan Packer dan Gross di atas, terlihat bahwa keduanya sebenarnya mengakui sifat dilematisnya masalah pemidanaan, di satu sisi dianggap sebagai penampakan sifat jahat (evi), disisi yang lain pemidanaan masih mempunyai kemanfaatan sehingga keberadaannya masih diperlukan tetapi untuk itu perlu adanya alasan pembenaran (justifikasi) yang tepat. Namun demikian harus pula diakui bahwa masih ada pandangan lain yang justru tidak menyetujuj adanya pemidanaan dengan alasan masingmasing, yang termasuk dalam hal ini misalnya Hulsman. ${ }^{10}$

Bagi mereka yang pemah belajar hukum pidana pastilah mengetahui bahwa salah satu sifat hukum pidana yang tidak terdapat dalam hukum yang lain terletak pada jenis dan sifat ancaman sanksi pidana yang bersifat lebih keras dibandingkan dengan peraturan hukum lainnya, karena ancaman sanksi pidana bisa berupa pencabutan atau pengurangan hak atas kepemilikan harta benda, pencabutan atau pengurangan hak-hak administratif tertentu, pengurangan kebebasan bergerak sementara waktu atau seumur hidup (hukuman badan), dan bahkan bisa pula berupa pencabutan nyawa. Dua terakhir dari empat macam ancaman sanksi pidana tersebut menurut penulis memang hanya terdapat dalam hukum pidana, sedang dua ancaman yang pertama dikenal dalam hukum keperdataan dan atau administratif."

Mengingat sifat ancaman sanksi dalam hukum pidana yang sangat keras tersebut, yaitu ancaman pidana badan dan pencabutan nyawa, dalam hukum pidana sebenarnya mengenal ajaran subsidiaritas, yang mengandung makna bahwa sebaiknya suatu perbuatan itu tidak diformulasikan sebagai perbuatan pidana menurut ketentuan hukum positif apabila dalam suatu masyarakat masih terdapat sarana-sarana yang lain untuk mempertahankan nilai-nilai atau normanorma kehidupan. Atau kalaupun diperlukan melalui pengaturan norma hukum sepanjang masih dimungkinkan untuk mengaturnya dengan norma hukum nonpidana, seperti hukum keperdataan, administratif, dan lain sebagainya, sebaiknya tidak perlu diformulasikan dalam rumusan hukum pidana. $^{12}$

Berdasarkan asas subsidiaritas tersebut menurut penulis, tidak semua masalah

${ }^{10}$ L.H.C. Hulsman, "Afscheid van Het Strafrecht Een Pleidooi Voor Zelfregulering", (teri) Wonosutanto, Selamat Tinggal Hukum Pidana! Menuju Swa-Regulasi Jilid 1 (Surakarta: Forum Studi Hukum Pidana Surakarta, 1988).

"Henry Campbell Black, Black's Law Dictionary: Definitions of the Terms and Phrases of American and English Jurisprudence, ancient and Modem, ST.Paul, Minn: West Publishing Co, 1990, sixth edition, hlm. 374. Criminal sanctions: "Punishment attached to conviction of crimes such as fines, restitution, probation, and sentences".

12 Sudarto, Hukum Pidana dan Perkembangan Masyarakat: Kajian Terhadap Pembaharuan Hukum Pidana (Bandung: Sinar Baru, 1983), hlm.58. 
kehidupan manusia dapat dan atau perlu diatur dengan hukum pidana, karena hukum pidana mempunyai keterbatasan kemampuan. Apabila terjadi suatu keadaan dimana sarana lain yang tersedia (dalam hal ini terutama norma nonhukum pidana) sudah tidak mampu mengatasi keadaan tertentu karena lemahnya sanksi, sehingga diperlukan suatu ancaman sanksi yang lebih kuat lagi, barulah diperlukan formulasi pengaturan ke dalam hukum pidana. Dalam hal ini hukum pidana difingsken sebagaiultimum remidium. ${ }^{13}$

Meskipun di dalam hukum pidana terdapat ajaran subsidiaritas sebagaimana yang telah dijelaskan di atas dan ditambah dengan keberadaan pemidanaan yang bersifat dilematis sehingga memunculkan banyak teori mengenai pembenaran pemidanaan, namun penulis melihat adanya fenomena terjadinya perkembangan (pertambahan) jumlah peraturan perundang-undangan pidana, baik yang terjadi ditingkat undang-undang maupun di tingkat peraturan-peraturan daerah. Dengan latar belakang seperti itu, fenomena terjadinya kriminalisasi tersebut menarik untuk dikaji.. ${ }^{14}$

\section{Kriminalisasi Dalam Perda-Perda Di Propinsi DIY'15}

Kriminalisasi adalah suatu proses dirumuskannya suatu perbuatan yang semula bukan merupakan perbuatan yang dapat dihukum dengan hukuman pidana, kemudian dirumuskan sebagai suatu perbuatan yang diancam dengan sanksi pidana dalam peraturan perundang-undangan. Kebalikan dari proses tersebut dinamakan sebagai dekriminalisasi yaitu suatu proses dimana dihilangkan sama sekali sifat dapat dipidananya suatu perbuatan yang semula diancam pidana oleh peraturan perundangundangan. ${ }^{16}$

Meskipun Indonesia telah mempunyai undang-undang hukum pidana yang dikodifikasikan dalam Kitab Undang-undang Hukum Pidana (KUHP), namun ternyata dalam perjalanan sejarahnya menunjukkan adanya proses kriminalisasi yang demikian pesat yang dimuat di luar KUHP. Ada beberapa faktor yang mempengaruhi berkembangnya hukum pidana di luar KUHP, antara lain:"

${ }^{13}$ Selain dapat difungsikan sebagai uttimum remidium, secara teoritik hukum pidana dapat juga difungsikan sebagai sarana utama untuk mempertahankan norma (fungsi primum remidium),

${ }^{14}$ Mengenai perkembangan peraturan perundang-undangan pidana tersebut akan dijelaskan dalam bagian lain makalah ini.

${ }^{15}$ Perda adalah singkatan dari Peraturan Daerah. DIY singkatan dari Daerah Istimewa Yogyakarta

${ }^{18}$ Sudarto, Hukum Pidana dan Perkembangan Masyarakat: Kajian Terhadap Pembaharuan Hukum Pidana (Bandung: Sinar Baru, 1983), hlm. 57. Dalam kamus hukum Black's istilah kriminalisasi (criminalization) diberi arti sebagai: "The rendering of an act criminal (e.g. by statutory enactment) and hence punishable by the government in a proceeding in its namen. Black, op.cit. hlm. 374.

${ }^{17}$ Andi Hamzah, Delik-Delik Tersebar Di Luar KUHP dengan Komentar (Jakarta: Pradnya Paramita, 1986), hlm. 1. 
1. Adanya perubahan sosial secara cepat sehingga perubahan-perubahan itu perlu disertai dan diikuti dengan peraturanperaturan hukum pula dengan sanksi pidana...

2. Kehidupan modern semakin kompleks, sehingga disamping adanya peraturan hukum (pidana) berupa unifikasi yang tahan lama (KUHP) diperlukan pula peraturan pidana yang bersifat temporer.

3. Banyak peraturan hukum berupa perundang-undangan di lapangan perdata, tata negara, dan terutama administrasi negara, perlu dikaitkan dengan sanksi-sanksi pidana untuk mengawasi peraturan-peraturan itu supaya ditaati...

Secara garis besar peraturan perundangundangan di bidang pidana di Indonesia dapat dibagi menjadi: ${ }^{18}$

1. Yang terdapat dalam kodifikasi, yaitu Kitab Undang-Undang Hukum Pidana (Kitab Undang-Undang Hukum Pidana) beserta dengan aturan perubahannya.

2. Yang terdapat di luar Kitab UndangUndang Hukum Pidana, terdiri dari dua macam yaitu:
a. Perundang-undangan Pidana Khusus.
b. Perundang-undangan Bukan Pidana yang mengandung sanksi pidana (Hukum Pidana Pemerintahan).

Secara umum dapat dikatakan bahwa Kitab Undang-Undang Hukum Pidana yang berlaku sejak Indonesia merdeka, beserta aturan penambah dan pengurangnya, relatif tidak begitu berbeda isinya dibandingkan dengan KUHP yang berlaku pada jaman penjajahan Belanda. Namun demikian, sebagaimana yang telah dikemukakan di bagian depan tulisan ini, perundangundangan pidana di luar KUHP ternyata menunjukkan perkembangan yang sangat pesat. Hamzah telah melakukan usaha untuk mengumpulkan peraturan hukum pidana di luar Kitab Undang-Undang Hukum Pidana tersebut. ${ }^{19}$ Hasil pengumpulan menunjukkan bahwa sampai dengan tahun 1987 saja terdapat delapan (8) perundang-undangan Pidana Khusus, dan empat puluh tujuh (47) Perundang-undangan di luar pidana yang bersanksi pidana (hukum pidana pemerintahan).

Pengumpulan perundang-undangan di bidang pidana tersebut sangat bermanfaat mengingat bahwa kemampuan daya ingat orang yang sangat terbatas, sehingga dengan pengumpulan peraturan tersebut dapat membantu orang untuk mengetahui peraturan yang berlaku. Dalam ilmu hukum dikenal adanya doktrin 'setiap orang dianggap mengetahui suatu peraturan yang telah secara resmi diundangkan. ${ }^{20}$ Sebagai akibat dari dianutnya doktrin ini maka setiap orang, tanpa

${ }^{18}$ Hamzah, ibid.

19 Ibid. hlm. ix - xv. Beberapa peraturan yang dihimpun tersebut sudah banyak yang mengalami perubahan baik karena penambahan, pencabutan,penggantian, atau muncul peraturan baru yang sebelumnya tidak ada misalnya Undang-Undang Pemberantasan Tindak Pidana Subversif, Undang-Undang Anti Narkotika, Undang-undang Pemberantasan Tindak Pidana Korupsi, Undang-Undang Psikotropika, Perundang-undangan di bidang Hak Atas Kekayaan Intelektual (HAKI) seperti hak cipta, hak paten, hak merek, hak disain industri dan lain sebagainya.

${ }^{20}$ Sudarto, op.cit. hlm. 6-7. 
kecuali, baik yang mempunyai latar belakang pendidikan hukum ataupun tidak, baik yang berada di pelosok pedalaman atau di perkotaan, dituntut untuk mengetahui semua peraturan yang berlaku'di suatu negara.

Bagi setiap warga negara berlaku doktrin teisebut, sehingga tidak ada alasan untuk berkelit dari pertanggungjawaban hukum meskipun dengan mengemukakan ketidaktahuan orang tentang hukum yang dimaksud. Doktrin tersebut dalam hukum pidana seringkali diparalelkan dengan asas legailitas ${ }^{21}$ yang menentukan bahwa setiap orang tidak dapat dipidana tanpa berdasar peraturan perundang-undangan hukum pidana yang telah ada sebelum peibuatan dilakukan.

Doktrin dalam hukum bahwa 'setiap orang dianggap mengetahui suatu peraturan yang telah secara resmi diundangkan' barangkali tidak akan menjadi masalah apabila negara yang menganut doktrin tersebut hanya mempunyai peraturan hukum pidana yang tidak banyak dan semuanya sudah dikodifikasi, serta wilayah geografisnya tidak luas dengan tingkat heteroginitas penduduknya yang tidak tinggi. Namun diperkirakan, pelaksanaan doktrin tersebut akan menjadi masalah apabila kondisi tersebut tidak terpenuhi. Mengenai hal ini Sudarto berpendapat bahwa adagium tersebut hanya sejalan dengan mereka yang berpandangan normatif-abstrak tentang hukum, karena doktrin tersebut bersifat fiktif, yang pada kenyataannya tidaklah mungkin ada orang yang mengetahui semua aturan dalam undang-undang. Sudarto pun tidak yakin apabila seseorang yang menjadi pejabat selalipun mengetahui emua peraturen.2

Indonesia dapat dijadikan sebagai suatu contoh kasus. Dengan luas wilayah demikian besar yang terdiri dari ribuan pulau dan berbagai macam suku dengan tingkat heteroginitas yang sangat tinggi, misalnya dilihat dari segi tingkat pendidikan, ekonomi dan sebagainya. Bagaimana mungkin kita menuntut agar orang lrian di pedalaman yang belum mengenal tradisi tulis dengan baik dipaksa untuk mengikuti doktrin tersebut, sedangkan mereka yang sudah sarjana hukum sekali pun secara faktual tidak mungkin dapat mengetahui seluruh hukum pidana yang berlaku yang tersebar dalam berbagai peraturan perundang-undangan.

Pengumpulan peraturan perundangundangan Pidana yang dilakukan oleh Andi Hamzah tersebut sebenarnya masih sangat jauh dari kondisi objektif yang ada, mengingat sebenarnya masih banyak peraturan daerah (Perda), baik yang diatur oleh propinsi ataupun kabupaten/kota, yang ternyata juga sering mencantumkan ancaman sanksi pidana dalam berbagai Perda yang dibuat meskipun Perda tersebut sebenarnya tidak mengatur bidang kepidanaan. Mengingat demikian banyaknya Perda-Perda di seluruh Indonesia tentunya hampir mustahil untuk dapat dikodifikasikan. Yang mungkin dapat dilakukan adalah melakukan inventarisasi terhadap perda-perda yang ada, sebagaimana yang telah dilakukan oleh Departemen Dalam

${ }^{21}$ Moéljatno, op.cit' hlm16-21. Wirjono Prodjodikoro, Asas-Asas Hukum Pidana diIndonesia (Bandung: Eresco, 1969), hlm. 32-38.

2 Sudarto, op.cit. hlm.6-7. 
Negeri. Dari seluruh pemerintah daerah di seluruh Indonesia, Departemen Dalam Negeri sampai dengan bulan November 2001 telah berhasil mengumpulkan sebanyak seribu limapuluh tiga (1.053) buah perda yang masih berlaku. ${ }^{23}$ Kondisi seperti ini dapat menyulitkan mereka yang ingin mengetahui atau mempelajari Perda-Perda tersebut, apalagi sistem pendokumentasian dan publikasinya masih manual dan terbatas.

Sampai dengan bulan Agustus 2001 terdapat empat puluh sembilan (49) Perda di Propinsi Daerah Istimewa Yogyakarta. ${ }^{24}$ Secara umum Peraturan Daerah tersebut dapat dibagi dalam dua kategori yaitu: yang bersifat pengaturan/perijinan dan pungutan (pajak dan retribusi). Dari empat puluh sembilan (49) Perda tersebut, sebanyak tiga puluh lima (35) bersifat pengaturan-perijinan, dan sisanya berkaitan dengan masalah pungutan.

Dari empat puluh sembilan (49) Perda tersebut ternyata sebanyak empat belas (14) Perda yang dapat diklasifikasikan ke dalam hukum pidana pemerintahan, mengingat semuanya sebenarnya bukan termasuk dalam kategori peraturan di bidang kepidanaan, namun lebih pada peraturan nonpidana tetapi terdapat ancaman sanksi pidana di dalamnya. ${ }^{25}$
Perda-perda di Propinsi Daerah Istimewa Yogyakarta yang termasuk dalam kategori peraturan hukum pidana pemerintahan tersebut adalah sebagaimana dijelaskan dalam tabel I dihalaman belakang artikel ini.

Dari tabel tersebut terlihat bahwa ada kecenderungan untuk memuat ancaman sanksi pidana dalam perda-perda yang mengatur mengenai pungutan (pajak dan retribusi). Dari sebanyak empat belas (14) perda yang bersanksi pidana tersebut, sebanyak sebelas (11) perda merupakan perda yang bersifat pengaturan-pemberian izin. Dari segi tingkat beratnya ancaman sanksi pidana sebagaimana telah dimuat dalam tabel $1 \mathrm{di}$ atas, terlihat bahwa ada juga perda yang memuat ancaman pidana relatif cukup tinggi yaitu dengan ancaman pidana penjara maksimal dua (2) tahun penjara.

Berdasarkan data dari Bagian Perundangundangan pada Biro Hukum Pemerintah Propinsi DIY semua perda yang masih berlaku di DIY tersebut terdapat empat (4) buah perda yang merupakan produk perda di bawah tahun 1970. Dua perda (2) merupakan produk tahun 1969, satu (1) perda produk tahun 1960, dan satu (1) perda yang paling lama berlakunya adalah perda Tentang Pengairan Daerah Istimewa Yogyakarta, yaitu Perda No. 28 Tahun 1956.

\footnotetext{
${ }^{23}$ Harian Kompas, 26 November 2001 "Soal Perda-Perda Bermasalah: Otonomi Daerah Yang Kebablasan?

${ }^{24}$ Diolah berdasarkan catatan Biro Hukum, Bagian Perundang-undangan, Propinsi Daerah Istimewa Yogyakarta; 14 September 2001.

${ }^{25}$ Tim Pembina Pelaksanaan Tugas-Tugas PPNS Pemerintah Propinsi Daerah Istimewa Yogyakarta, Himpunan Peraturan Perundang-undangan Yang Menjadi Dasar Hukum PPNS Di Lingkungan Pemerintah Propinsi Daerah Istimewa Yogyakarta Buku I, II, dan III, Yogyakarta: tidak dipublikasikan untuk umum, 1999. Untuk selanjutnya sumber data atau informasi mengenai Perda-perda yang diambil untuk keperluan tulisan ini akan diambilkan dari buku himpunan tersebut.
} 
Dari.semua perda di DIY yang masih berlaku tersebut, yang dihasilkan di bawah tahun 1994 tidak ada satu pun yang memuat rumusan ancaman sanksi pidana. Adanya rumusan ancaman sanksi pidana yang dimasukkan ke dalam perda di DIY baru terlihat semenjak munculnya Perda No. 9 Tahun 1994 Tentang Retribusi Masuk Taman Wisata Alam Plawangan Turgo. Kemudian sesudah itu dimulailah era kecenderungan untuk memasukkan rumusan ancaman sanksi pidana.ke dalam perda-perda di DIY terutama pada perda-perda yang mengatur tentang pungutan daerah. Dari 14 perda di DIY yang memuat ancaman sanksi pidana, hanya ada 3 perda yang bersifat pengaturan-perizinan.

Ditemukannya kecenderungan untuk memberikan rumusan ancaman pidana dalam perda-perda di DIY, khususnya yang berkaitan dengan masalah pungutan daerah tersebut dilihat dari perspektif hukum pidana nampaknya diletakkan sebagai norma pengaturan yang bersifat sosial ekonomis yang bersifat memaksakan. Dengan demikian tujuan utama dari pemuatan ancaman sanksi pidana dalam peraturan nonpidana tersebut sebenamya hanya untuk memaksakan agar masyarakat mentaati isi perda tersebut. ${ }^{26}$

Semua perda yang memuat ancaman sanksi pidana sebagaimana dimuat dalam tabel 1 di atas, mengandalkan proses penyidikannya pada Penyidik Pegawai Negeri
Sipil tertentu sebagaimana dimuat dalam Pasal 6 Kitab Undang-Undang Hukum Acara Pidana (KUHAP), hanya ada satu Perda yang penyidikannya dimungkinkan dilakukan oleh Penyidik Polri yaitu Perda No. 3/1999 Tentang Izin Trayek. ${ }^{27}$ Berdasarkan Perda-Perda tersebut petugas penuntut dan pengadilan yang akan memeriksa dan mengadili perkaraperkara delik Perda tersebut sama seperti delik-delik lainnya. Dengan demikian tidak ada peradilan yang khusus untuk memeriksa dan mengadili perkara pidana pelanggaran Perda tersebut.

Setiap langkah.kebijakan, 'termasuk dalam hal ini kebijakan untuk melakukan proses kriminalisasi, tentu dapat menimbulkan konsekuensi logis tertentu. Konsekuensi logis yang mungkin akan muncul sebagai akibat dari kriminalisasi sepanjang yang mampu didentifikasi menurut penulis adalah sebagai berikut:

\section{a. Reaksi Masyarakat}

Masyarakat dapat mierespon dan memberikan reaksi atas setiap proses kriminalisasi, baik yang bersifat menyetujui (dengan atau tanpa persyaratan tertentu), atau bahkan berupa penolakan. Materi tertentu yang diatur dalam suatu peraturan perundang-undangan jika merupakan sesuatu yang sangat sensitif misalnya menyangkut masalah agama, kepercayaan, ideologi, atau menyangkut

${ }^{26}$ Hukum pidana pemerintahan kadang-kadang disebut pula sebagai "ordeningsstrafrechf' yang Menurut Roeslan Saleh dianggap sebagai penutup suatu pengaturan yang bersifat sosial ekonomis dari Pemerintah yang bersifat memaksakan. Lihat Hamzah, op.cit. hlm. 4.

${ }^{27}$ Undang-Undang nomor 8 tahun 1981 tentang Kitab Undang-Undang Hukum Acara Pidana (KUHAP) dalam Pasal 6 ayat (1) menentukan bahwa yang dapat menjadi penyidik adalah pejabat polisi negara Republik Indonesia, dan pejabat pegawai negeri sipil tertentu yang diberi wewenang khusus oleh undang-undang. 
hajat hidup orang banyak, seringkali dapat menimbulkan suasana perdebatan (prokontra) yang jika kepentingan masyarakat yang akan terkena peraturan tersebut tidak diakomodasi dengan baik dapat menimbulkan keadaan yang kontra produktif.

b. Tambahan Beban Terhadap Sistem Peradilan Pidana

Bagaimanapun setiap ada pertambahan perundang-undangan pidana dapat menyebabkan tambahan beban terhadap sistem peradilan pidana, baik beban administratif, keuangan, dan kemampuan aparatur untuk melaksanakan upaya penegakan hukum pidana.

c. Kesiapan Masyarakat Untuk Menerima Peraturan Baru

Masyarakat perlu dipersiapkan dengan sebanik-baiknya untuk menerima kehadiran suatu peraturan baru, sehingga dengan demikian diperlukan langkahlangkah sosialisasi sebelum suatu peraturan diberlakukan.

Berkaitan dengan masalah tersebut, menurut Barda proses kriminalisasi harus memperhatikan berbagai aspek pertimbangan sebagai berikut ${ }^{28}$

a. Penggunaan hukum pidana harus memperhatikan tujuan pembangunan nasional, yaitu mewujudkan masyarakat adil dan makmur yang merata material spiritual berdasarkan Pancasila; sehubungan dengan ini maka (penggunaan) hukum pidana bertujuan untuk menanggulangi kejahatan dan mengadakan pengugeran terhadap tindakan penanggulangan itu sendiri, demi kesejahteraan dan pengayoman masyarakat.

b. Perbuatan yang diusahakan untuk dicegah atau ditanggulangi dengan hukum pidana harus merupakan perbuatan yang tidak dikehendaki, yaitu perbuatan yang mendatangkan kerugian (material dan atau spiritual) atas warga masyarakat.

c. Penggunaan hukum pidana harus pula memperhitungkan prinsip biaya dan hasil (cost and benefit principles) juga social cost atau biaya sosial.

d. Penggunaan hukum pidana harus pula memperhatikan kapasitas atau kemampuan daya kerja dari badanbadan penegak hukum, yaitu jangan sampai ada kelampauan beban tugas (overbelasting).

Hampir semua perda yang bersanksi pidana yang berlaku di Propinsi DIY mengandalkan proses pemeriksaan penyelidikan dan penyidikannya pada penyidik pegawai negeri sipil tertentu di lingkungan Propinsi DIY, maka tentu saja diperlukan banyak kesiapan baik dari segi kuantitas dan kualitas aparatur penyidik, fasilitas yang diperlukan oleh penyidik, hingga masalah kesungguhan sikap politik pemerintah daerah (good will) untuk melaksanakan proses penyidikan dengan sebaik-baiknya.

${ }^{28}$ Barda Nawawi Arif, Bunga Rampai Kebijakan Hukum Pidana (Bandung: PT. Citra Aditya Bakti, 1996), hilm. 33-34: 
Berdasarkan hasil wawancara dengan petugas di Bagian Perundang-undangan pada Biro Hukum Pemerintah Propinsi DIY diperoleh informasi bahwa Pemerintah Propinsi DIY sendiri mempercayakan sepenuhnya pelaksanaan isi perda-perda tersebut pada Dinas-Dinas terkait. Misalnya perda yang mengatur bidang pariwisata akan ditangani langsung oleh Dinas Pariwisata, yang mengatur bidang kesehatan oleh Dinas Kesehatan, yang mengatur masalah izin trayek akan ditangani oleh Dinas Lalu Lintas dan Angkutan Jalan Raya (DLLAJ) dan lain sebagainya. ${ }^{29}$

Demikian juga masalah penanganan monitoring terhadap pelaksanaan perdaperda tersebut juga diserahkan pada dinasdinas terkait. Dengan demikian apabila kita ingin mengetahui bagaimana pelaksanaan perda-perda tersebut, khususnya yang berkaiatan dengan penegakan hukum pidananya kita harus melakukan pengumpulan data pada dinas-dinas tersebut karena data tersebut tidak tersedia di tingkat Bagian atau Biro. Di tingkat Bagian atau Biro tidak ada data statistik yang memadai yang dapat dipakai sebagai dasar analisis untuk membuat penilaian tingkat efektivitas ancaman sanksi pidana dalam perda-perda yang berlaku di Pemerintah Propinsi DIY.30
Berdasarkan wawancara penulis dengan Petugas di Bagian Perundang-undangan pada Biro Hukum Pemerintah Propinsi DIY diperoleh kesan bahwa sepanjang masih terdapat sarana lain untuk menegakkan ketentuan yang terdapat dalam perda, maka tidak akan dilakukan proses peradilan pidana terhadap para pelanggar hukum pidana yang diatur dalam perda-perda tersebut. Dengan demikian meskipun dalam praktek di lapangan ditemukan adanya pelanggaran perda yang memungkinkan untuk dilakukan proses penyidikan. sepanjang dapat diselesaikan dengan sarana yang lain maka yang akan dipilih untuk dilakukan adalah dengan mempergunakan sarana lain di luar hukum pidana misalnya dengan mendasarkan pada kewenangan untuk melakukan diskresi. ${ }^{31}$

\section{Simpulan}

Berdasarkan uraian di atas kita telah mengetahui bahwa meskipun perda-perda yang mengatur masalah-masalah nonpidana beberapa diantaranya telah memuat ancaman sanksi pidana, yang mestinya dapat difungsikan sebagai sarana untuk memaksakan berlakunya perda tersebutagar masyarakat taat dan patuh kepada perda tersebut, namun kenyataan menunjukkan

${ }^{29}$ wawancara dengan petugas di Bagian Perundang-undangan pada Biro Hukum Pemerintah Propinsi DIY, tanggal 14 September 2001. Wawancara diadakan khusus untuk maksud penulisan makalah ini.

${ }^{30}$ Penulis belum menyempatkan diriuntuk mencari data tersebut di Biro Pusat Statistik Pemerintah PropinsiDIY.

${ }^{31}$ Tanpa bermaksud untuk menutup "mata" terhadap adanya pengertian atau pemahaman yang lain, istilah diskresi yang dipakai disini diartikan sebagai "Kemungkinan menentukan sendiri keputusan yang diambil dari beberapa kemungkinan sebagai alternatif'. Roeslan Saleh, Dari Lembaran Kepustakaan Hukum Pidana (Jakarta: Sinar Grafika, 1988), hlm. 155. Lihatjuga M. Faal, Penyaringan Perkara Pidana Oleh Polisi (Diskresi Kepolisian) (Jakarta: Pradnya Paramita, 1991). Pengecekan informal yang dilakukan di Pengadilan Negeri Yogyakarta didapatkan informasi bahwa di Pengadilan Negeri Yogyakarta sendiripun tidak tersedia data mengenai 
bahwa pelanggaran terhadap ketentuan pidana yang ada dalam perda tersebut tidak dilakukan proses peradilan pidana sebagaimana mestinya. Setidak-tidaknya dalam hal ini penulis tidak mendapatkan gambaran yang jelas mengenai usaha yang . telah dilakukan oleh Pemerintah Propinsi DIY dalam rangka penegakan hukum pidana yang dimuat dalam perda-perda di DIY, karena tidak tersedianya data mengenai hal itu.

Fenomena demikian tentunya menarik untuk dikaji dalam perspektif politik kriminal.

Menurut Sudarto yang dimaksud dengan politik kriminal adalah "Suatu usaha yang rasional dari masyarakat dalam menanggulangi kejahatan". Definisi singkat ini sebenarnya mengambil dari Marc Ancel dalam bukunya "The rational organization of the control of crime by society". Sedang secara terperinci pengertian politik kriminal menurut Sudarto adalah: ${ }^{32}$

a. dalam arti sempit, ialah keseluruhan asas dan metode yang menjadi dasar dari reaksi terhadap pelanggaran hukum yang berupa pidana;

b. dalam arti luas, ialah keseluruhan fungsi dari aparatur penegak hukum, termasuk di dalamnya cara kerja dari pengadilan dan polisi;

c. dalam arti paling luas, ialah keseluruhan kebijakan, yang dilakukan melalui perundang-undangan dan badan-badan resmi, yang bertujuan untuk menegakkan norma-norma sentral dari masyarakat.
Berdasarkan pengertian politik kriminal tersebut terjadinya kriminalisasi dalam perdaperda di DIY yang tidak diimbangi dengan kebijakan untuk menegakkan ancaman sanksi pidana dalam perda tersebut merupakan fenomena yang mengherankan penulis. Bagaimana bisa terjadi suatu proses kriminalisasi yang tidak diimbangi dengan kebijakan penegakan hukum pidana. Menurut penulis, fenomena ini dapat menimbulkan kesan bahwa temyata ancaman pidana dalam perda tersebut hanya sebagai perhiasanasesori, yang tidak akan menimbulkan akibat hukum apapun jika dilakukan pelanggaran. Dari segi psiko-sosial kondisi seperti itu diperkirakan dapat menurunkan tingkat kesadaran hukum masyarakat, dan pada akhirnya masyarakat akan menganggap ancaman pidana tersebut tidak ada. Jika kondisi psiko-sosial masyarakat menjadi seperti itu maka tujuan dilakukannya proses kriminalisasi dkhawatirkan tidak akan tercapai.

Agar tujuan kriminalisasi tercapai diperlukan langkah-langkah kebijakan yang menyeluruh, untuk itu, tidak cukup jika hanya berhenti pada dirumuskannya suatu perbuatan menjadi. perbuatan pidana dalam hukum pidana positif, proses kriminalisasi seharusnya dikaitkan juga dengan politik kriminal dalam arti yang luas. Proses kriminalisasi dan politik kriminal mempunyai tujuan akhir yang sama yaitu untuk mencapai kesejahteraan dan keadilan masyarakat sedang menurut Sudarto adalah sebagai "Perlindungan masyarakat

peradilan terhadap kasus pelanggaran hukum pidana yang diatur dalam perda-perda di Propinsi DIY.

${ }_{32}$ Sudarto, Kapita Selekta Hukum Pidana (1981), hlm. 159, dan Hukum dan Hukum Pidana (1981), hlm. 161. dikutip dari Barda Nawawi Arif, Bunga Rampai Kebijakan Hukum Pidana (Bandung: PT. Citra Aditya Bakti,1996), hlm 27-28. 
untuk mencapai kesejahteraan masyarakat. ${ }^{n 3}$

Berdasarkan semua uraian yang telah dikemukakan di atas, dapat disimpulkan bahwa dilakukannya proses kriminalisasi dalam beberapa perda di Propinsi Daerah Istimewa Yogyakarta ternyata belum diimbangi dengan politik kriminal yang memadai. Agar tidak terjadi keadaan yang bersifat kontra produktif karena masyarakat menjadi tidak taat dan tidak patuh kepada hukum sebagai akibat dari sikap tindak aparatur penegak hukum sendiri yang tidak mau menegakkan hukum maka sebaiknya para pembuat peraturan perundang-undangan perlu mengkaitkan dengan dengan politik kriminal dalam arti yang luas sebelum melakukan kriminalisasi.

Tabel: 1

Dafar Perda Propinsi DIY yang Memuat Ancaman Sanksi Pidana

\begin{tabular}{|c|c|c|c|}
\hline No & $\begin{array}{l}\text { Mo./Th. } \\
\text { Perda }\end{array}$ & Mengatur Tentang & Keterangan \\
\hline 01 & $9 / 4994$ & $\begin{array}{l}\text { Retribusi Masuk Taman Wisata } \\
\text { Alam Plawangan Turgo }\end{array}$ & $\begin{array}{l}\text { - Sifat Peraturan: Pungutan } \\
\text { - Perda lengkapnya belum ditemukan penulis }\end{array}$ \\
\hline 02 & $2 / 1997$ & $\begin{array}{l}\text { Pramuwisata \& Usaha Jasa } \\
\text { Pramuwisata }\end{array}$ & $\begin{array}{l}\text { - Sifat Peraturan: : Pengaturan - Perizinan } \\
\text { - Perda lengkapnya belum ditemukan penulis }\end{array}$ \\
\hline 03 & $3 / 1997$ & Izin Pembuangan Limbah Cair & $\begin{array}{l}\text { - Sifat Peraturan: Pengaturan } \\
\text { - Perda lengkapnya belum ditemukan penulis }\end{array}$ \\
\hline 04 & $3 / 1998$ & Pajak Kendaraan Bermotor & $\begin{array}{l}\text {-Sifat Peraturan: Pungutan } \\
\text { - Membedakan delik kealpaan dan kesengajaan. } \\
\text { Bentuk delik \& ancaman pidana diatur dalam Ps. } \\
\text { 30. Alpa: Kurungan maks. } 1 \text { th. \&/ denda maks. } 2 X \\
\text { pajak terutang. Sengaja: penjara maks. } 2 \text { th. \& } \\
\text { denda mks } 4 \text { X pajak terutang. } \\
\text { - Penyidik: PPNS }\end{array}$ \\
\hline 05 & 4/1998 & $\begin{array}{l}\text { Bea Balik Nama Kendaraan } \\
\text { Bermotor (BBN-KB) }\end{array}$ & $\begin{array}{l}\text {-Sifat Peraturan: Pungutan } \\
\text { - Membedakan delik kealpaan dan kesengajaan. } \\
\text { Bentuk delik \& ancaman pidana diatur dalam Ps. } \\
\text { 29. Alpa: Kurungan maks. } 1 \text { th. \& denda maks. } 2 \\
\text { X pajak terutang. Sengaja: penjara maks. } 2 \text { th. \& } \\
\text { denda mks } 4 \text { X pajak terutang. Penyidik: PPNS. }\end{array}$ \\
\hline 06 & 9/1998 & $\begin{array}{l}\text { Retribusi Penjualan Produksi } \\
\text { Usaha Daerah }\end{array}$ & $\begin{array}{l}\text { - Sifat Peraturan: Pungutan } \\
\text { - Ps.14: Kurungan maks. } 6 \text { bulan, atau denda } 4 X \\
\text { retribusi terutang. (Pelanggaran). Penyidik: PPNS }\end{array}$ \\
\hline 07 & $13 / 1998$ & $\begin{array}{l}\text { Pajak Bahan Bakar } \\
\text { Kendaraan Bermotor }\end{array}$ & $\begin{array}{l}\text {-Sifat Peraturan: Pungutan } \\
\text { - Ps.34 Membedakan delik kealpaan dan kesengajaan. } \\
\text { Bentuk delik \& ancaman pidana diatur dalam Ps. } \\
\text { 34. Alpa: Kurungan maks. } 1 \text { th. \&/ denda maks. } 2\end{array}$ \\
\hline
\end{tabular}

${ }^{33}$ Sudarto, Kapita Selekta Hukum Pidana, 1981 hlm. 159, dan Hukum dan Hukum Pidana, 1981, him.161. dikutip dari Barda Nawawi Arif, Bunga Rampai Kebijakan Hukum Pidana, Bandung: PT. Citra Aditya Bakti,1996, hlm 27-28. 


\begin{tabular}{|c|c|c|c|}
\hline & & & $\begin{array}{l}\text { X pajak terutang. Sengaja: penjara maks. } 2 \text { th. } \& J \\
\text { denda mks } 4 \text { X pajak terutang (pelanggaran). }\end{array}$ \\
\hline 08 & $3 / 1999$ & Retribusi Izin Trayek & $\begin{array}{l}\text { - Sifat Peraturan:: Pungutan } \\
\text { - Ps. } 26 \text { (1) Kurungan maks. } 3 \text { bln. Atau denda maks. } \\
\text { Rp } 50.000,00 \text {. (2) Kurungan maks. } 6 \text { bln. Atau } \\
\text { denda maks. } 4 \text { Xretribusi terutang. (Pelanggaran). } \\
\text { Penyidik: Polri dan PPNS. }\end{array}$ \\
\hline 09 & $5 / 1999$ & Retribusi Pelayanan Kesehatan & $\begin{array}{l}\text { - Sifat Peraturan: Pungutan } \\
\text { - Ps. } 26 \text { (1) Kurungan maks. } 6 \text { bln atau denda maks. } \\
4 \text { X retribusi terutang } \\
\text { - (pelanggaran). Penyidik: PPNS. }\end{array}$ \\
\hline 10 & $6 / 1999$ & $\begin{array}{l}\text { Retribusi Tempat Penginapan } \\
\text { /Pesanggrahan Nilla }\end{array}$ & $\begin{array}{l}\text { - Sifat Peraturan: Pungutan } \\
\text { - Ps. } 24 \text { (1) Kurungan maks. } 6 \text { bln atau denda maks. } \\
4 \mathrm{X} \text { retribusi terutang. } \\
\text { - Pelanggaran. Penyidik : PPNS }\end{array}$ \\
\hline 11 & $7 / 1999$ & $\begin{array}{l}\text { Retribusi Pemakaian } \\
\text { Kekayaan Daerah }\end{array}$ & $\begin{array}{l}\text { - Sifat Peraturan: Pungutan } \\
\text { - Ps. } 25 \text { (1) Kurungan maks. } 6 \text { bln atau denda maks. } \\
\text { Rp } 5.000 .000,00 \\
\text { - (Pelanggaran). Penyidik : PPNS }\end{array}$ \\
\hline 12 & $3 / 2000$ & $\begin{array}{l}\text { Penanggulangan dan Pemberantasan } \\
\text { Penyalahgunaan Narkotika, } \\
\text { psikotopika, dan Zat Aditif Lainnya } \\
\text { (NAPZA) }\end{array}$ & $\begin{array}{l}\text { - Sifat Peraturan: Pengaturan } \\
\text { - Perdalengkapnya belum ditemukan }\end{array}$ \\
\hline 13 & $4 / 2000$ & $\begin{array}{l}\text { Tata Tertib Penggunaan Asrama } \\
\text { Buruh Ledok Code }\end{array}$ & - Sifa! Peraturan: Pengaturan \\
\hline 14 & $1 / 2001$ & $\begin{array}{l}\text { Retribusi Pasar Grosir dan atau } \\
\text { Pertokoan }\end{array}$ & - Sifat Peraturan: Pungutan \\
\hline
\end{tabular}

\section{Daftar Pustaka}

Amin, Soleh dan Artidjo Alkostar, Pembangunan Hukum dalam Perspektif Politik Hukum Nasional, Jakarta: Rajawali, 1986.

Arief, Barda Nawawi, Bunga Rampai Kebijakan Hukum Pidana, Bandung: Citra Aditya Bakti, 1986.

\section{-_. Kebijakan Legislatif Dalam Penanggulangan Kejahatan Dengan Pidana Penjara, Semarang: Ananta,}

1994.

Masalah Penegakan Hukum dan Kebijakan Penanggulangan Hukum Pidana, Bandung, Citra Aditya Bakti, 2001.

Black, Henry Campbell. Blak's Law Dictionary: Defininitions of the Terms and Phrases of American and English Jurisprudence, Ancient and Modem, ST. Paul, Minn: West Publishing Co. 1990, sixth edition. 
Faal, M. Penyaringan Perkara Pidana Oleh Polisi (Diskresi Kepolisian), Jakarta: Pradnya Paramita, 1991.

Hamzah, Andi. Delik-Delik Tersebar Di Luar KUHP Dengan Komentar, Jakarta: Pradnya Paramita, 1986.

Hanafi, Politik Hukum Pidana, Yogyakarta: Perpustakaan Fakultas Hukum UII, 1998.

Hulsman, L.H.C. Selamat Tinggal Hukum Pidana ! Menuju Swa-Regulasi, terjemahan Wonosutanto dari edisi berbahasa Belanda "Afscheid Van Het Strafrecht Een Pleidooi Voor Zelfregulering", Surakarta: Forum Studi Hukum Pidana Surakarta, 1988.

Muladi dan Barda Nawawi Arief, Bunga Rampai Hukum Pidana, Bandung: Alumni, 1992.

Teori-Teori dan Kebijakan Pidana, Bandung: Alumni, 1992.

Nusantara, Abdul Hakim G. et.al.eds. Kitab Undang-Undang Hukum Acara Pidana dan Peraturan-Peraturan Pelaksana, Jakarta: Djambatan, 1992. Cetakan kedua.

NN, Masalah Pembaharuan Kodifikasi Hukum Pidana Nasional Buku I, kumpulan kertas kerja Lokakarya, Jakarta: BPHNDerpartemen Kehakiman RI, 1984.

Saleh, Roeslan. Suatu Reorientasi Dalam Hukum Pidana, Jakarta: Aksara Baru, 1978.

, Dari Lembaran Kepustakaan Hukum
Pidana, Jakarta: Sinar Grafika, 1988.

Sianturi, SR. Asas-Asas Hukum Pidana di Indonesia dan Penerapannya, Jakarta: Alumni AHAEM dan PETEHAEM, 1986.

Sudarto, Hukum Pidana dan Perkembangan Masyarakat, Kajian Terhadap Pembaharuan Hukum Pidana, Bandung: Sinar Baru, 1983.

\section{Peraturan Perundang-undangan}

NN, Himpunan Juklak dan Juknis Tentang Penyidik Pegawai Negeri Sipil, Yogyakarta: Tim Pembina Pelaksanaan Tugas-Tugas PPNS Pemerintah Propinsi DIY, 1997.

Himpunan Peraturan Perundangundangan Yang Menjadi Dasar Hukum PPNS Di Lingkungan Pemerintah Propinsi DIY Buku II, Yogyakarta: Tim Pembina Pelaksanaan Tugas-Tugas PPNS Pemerintah Propinsi DIY, 1999.

, Himpunan Peraturan Perundangundangan Yang Menjadi Dasar Hukum PPNS Di Lingkungan Pemerintah Propinsi DIY Buku III, Yogyakarta: Tim Pembina Pelaksanaan Tugas-Tugas PPNS Pemerintah Propinsi DIY, 1999.

Undang-Undang Republik Indonesia Nomor 22 Tahun 1999 Tentang Pemerintah Daerah.

Undang-Undang Republik Indonesia Nomor 25 Tahun 1999 Tentang Perimbangan Keuangan Antara Pemerintah Pusat dan Daerah. 